\title{
THE SYSTEM OF VALUES AND PERCEPTION OF TIME IN THE TRANSITIONAL SOCIETY: SOCIO-PSYCHOLOGICAL ISSUES AND PERSPECTIVES
}

\author{
Irina CAUNENCO1, PhD in Psychology, Associate Professor, \\ Institute of Cultural Heritage, Republic of Moldova \\ Lucia GASPER ${ }^{2}$, PhD in Psychology, Senior Researcher, \\ Institute of Legal, Political and Sociological Research, Republic of Moldova
}

DOI: https://doi.org/10.36004/nier.es.2019.2-08

JEL Classification: I25, I29, J15, J24

UDC: 316.6

\section{ABSTRACT}

The empirical study of the time and values system perception in different social ethnic and age groups offers the possibility to understand the potential subjectivity of groups in transitional society. The goal of the research was the study of time perception, values system in different age and ethnic groups in the transitional society. The methodological basis of our research is the systemic approach and social constructivism. Social groups were studied - age groups (adolescents, youngers, adults); ethnic groups (Gagauz people, Ukrainians, Bulgarians, Russians). In order to carry out the empirical research, standardized methods and semi-structured interview were applied: "The Scale of Time Attitudes" Nutten J.; semi-structured interview on time perception; the method elaborated by E. B. Fantalova. It was revealed that the groups of Russians, Bulgarians are characterized by a positive perception of present time, but the Gagauz people and Ukrainians perceived less positive the present time. Time perspective of these groups is short-from one year to five years - that can be an evidence of difficulties met by these groups in today transitional reality of the country. There were determined groups of youngers on time perception from optimistic to socialanxious (the given type, potential for migration). The study of values system of adolescent respondents from rural areas (most have parents working abroad) showed the importance of such values as health, happy family life and at the same time, the complexity of their basic needs' satisfaction.

Keywords: large social groups, time perspective, time perception, present time perception, ethnic groups, age groups, value, value system, transitional society, worldview, social time.

Studiul empiric al percepției timpului și a sferei valorice la diferite grupuri sociale-etnice, de vârstă - face posibilă înțelegerea potențialului subiectivității grupurilor într-o societate tranzitivă. Studiul a avut ca scop studierea percepției timpului, sferei valorice de către diferite grupuri de vârstă și etnice în societatea tranzitivă. Drept bază metodologică a studiului a fost abordarea sistemică și constructivismul social. Au fost studiate grupurile sociale de vârstă - adolescenți, tineri, adulți și etnice -găgăuzi, ucraineni, bulgari și ruşi. Pentru realizarea studiului empiric s-au aplicat tehnici standardizate și interviul semistructurat: "Scala atitudinilor de timp" de Nutten J., interviul semistructurat privind percepția timpului, metoda elaborată de E.B.Fantalova. S-a determinat că la grupurile de ruși și bulgari prevalează o percepție pozitivă a prezentului, pe când la găgăuzi și ucraineni fiind mai redusă. Perspectiva de timp a acestor grupuri este de scurtă durată, de la unu la cinci ani, ce poate indica dificultăți în depășirea perioadei de tranzitivitate la grupurile respective. Se disting grupuri de tineri în percepția timpului, de la optimiști la anxioși-social (un tip potențial de emigrare). Un studiu asupra sferei valorice a adolescenților respondenți din mediul rural (cu părinți plecați peste hotare) a dezvăluit prioritatea valorilor - sănătate, o viață de familie fericită și, în același timp, dificultatea în realizarea acestor valori.

Cuvinte-cheie: grupuri sociale mari, perspectiva de timp, percepția timpului, grupuri etnice, grupuri de vârstă, valori, societate tranzitivă, orientări valorice, imaginea lumii, timp social.

1 (C) Irina CAUNENCO, caunencoi@mail.ru

2 (C) Lucia GASPER, gasperlucia@mail.ru 
Эмпирическое исследование восприятия времени и ценностной сферы у этнических и возрастных социальных групп даёт возможность понимания потенциала субъектности групп в транзитивном обществе. Целью исследования явилось изучение восприятие времени, ценностной сферы разными возрастными и этническими группами в транзитивном обществе. Методологическая основа исследования: системный подход и социальный конструктивизм. Исследовались социальные группы - возрастные (подростки, молодёжь, взрослые); этнические (гагаузы, украинцы, болгары, русские). Для реализации эмпирического исследования были применены стандартизированные методики и полуструктурированное интервью: «Шкала временных установок» Нюттен Ж.; полуструктрированное интервью по восприятию времени; методика Е.Б.Фанталовой.

Выявлено, что у групп русских и болгар доминирует позитивное восприятие настоящего времени, тогда как у гагаузов и украинщев оно несколько ниже. Временная перспектива данных групп короткая, от года до пяти лет, что может свидетельствовать о сложностях прохождения периода транзитивности у данных групп. Выделены группы молодёжи по восприятию времени от оптимистического, до социально-тревожного (данный типпотенциал для эмиграции). Исследование ценностной сферы респондентов подросткового возраста из сельской местности, у которых большинство родителей находятся на заработках, выявило значимость ценностей - здоровья, счастливой семейной жизни, и в то же время сложности в их удовлетворении.

Ключевые слова: большие социальные группы, временная перспектива, восприятие времени, этнические группы, возрастные группы, ценности, транзитивное общество, ценностные ориентации, картина мира, социальное время.

INTRODUCTION. The research of large social groups in the period of transition presents a great interest for us, because the content of socially important features of human psychic are developed at macro-social level, where, from historical perspective, concrete social rules, values, attitudes and representations are formed, which in their turn are "delivered" to the individual through small groups and interpersonal communication [6, DILEGENSKIJ, G.G., 1994].

Large social groups are perceived as "natural" due to the length of their existence. The culturalpsychological originality of the given groups is formed historically, by the efforts of some generations which determine the orderliness, stability of group values, and rules of behavior and conduct. The agents of ethnic, gender-role, religious, and political socialization are represented by the members of immediate social environment.

The members of a large social group are linked by symbolic relations generated by the similarity of conditions, life style, values, experiences, and in ordinary circumstances such groups represent a community only in the consciousness of its members [5, BOGOMOLOVA, N.N. et al., 2002].

The research of large social groups is determined by the need of understanding the deep changes in a transitional society.

In the psychological content of the notion "society in transition" includes:

- fundamental social transformations;

- globalization that leads to the expansion of the space of interpersonal interactions;

- emphasis of social uncertainty related to frequent transformations of values, norms and standards;

- increase of the length of the time period of the socialization process, the intensification of re-socialization and current socialization;

- expansion of informational space, partially replacing intergenerational relations [13, MARCINKOVSKAÂ, T.D., 2015].

Nowadays, time categories play more and more a substantial role in forming the group identity and in the "imaginary communities" [1, ANDERSON, Benedikt., 2016].

In the conditions of transitional society, the individual and age groups need understanding and ways of owning personal time, because these represent an important condition of collective subjectivity. As "group attitude to time" we understand the peculiarities of perception, experience, awareness and management of time which are typical to the members of a certain social group [7, KRIVCOVA, S.V., 1997]. 
We define social time: firstly, as objective relations of antecedence, subsequence and simultaneity between people actions, social phenomena and processes; secondly, as subjective mirroring of these relations in the group consciousness [7, KRIVCOVA, S.V., 1997].

The social psychologist G. M. Andreyeva points that the "problem of 'insertion' in the historical time stands especially sharp in situations of radical social transformations... and an important stage in this process is represented by the understanding of time" [2, ANDREEVA, G.M., 2009].

The research of the problem of the attitude to time is studied on societal, group. Interpersonal, and intrapersonal levels [9. Nestik, T., 2014; 16, SYRCOVA A., MITINA O.V., et al., 2007; 14, EMEL'ÂNOVA, T.P., 2006; 15, KUZNECOVA, A.V., 2013].

We find very interesting for our research, the results of empirical studies regarding the manifestation of the phenomenon of time perspective in different cultures, conducted by researchers (Apostolidis T., Fieulaine N., 2004; Boyd J.N., Zimbardo P.G., 1999, 2005; Keough K.A., Zimbardo P.G., Boyd J.N., 1999; Syrtsova A., Mitina O.V., Boyd J., Davydova I.S., Zimbardo F., Nepryaho T.L., Nikitina E.A., Semenova, 2007) from different countries (France, USA, Russia).

Time perspective is defined by the give researchers as "a fundamental and unconscious process, by which social and individual experience is correlated with time categories, which allows to give meaning and coherence to the lived experience" [16, SYRCOVA, A., MITINA, O.V. i dr., 2007].

The research of time perspective in Italy (D Alessio M., Guarino A., Vilfredo De Pascalis V., Zimbardo Ph., 2003) revealed a significant correlation between time perspective and level of education. The researchers presupposed that the low educational level having a direct proportional relation with low socio-psychological statute, when nothing depends on a person's desires, could lead to the formation of a passive submission to events. [16, SYRCOVA, A., MITINA, O.V. i dr., 2007].

The research of time perspective in France (Apostolidis T., Fieulaine N., 2004) reveals that adverse situations are associated with a lesser orientation toward the future, and with a greater orientation toward the present and past. Focusing on a negative past is accompanied by a significant decrease in psychological well-being. These results confirm the relationship of the time perspective with the social conditions of existence and its role in subjective well-being. [16, SYRCOVA, A., MITINA, O.V. i dr., 2007].

A study of the time perspective in Russia (Syrtsova A., Mitina O.V., Boyd J., Davydova I.S., Zimbardo F., Nepryaho T.L., Nikitina E.A., Semenova, 2007). It was found that younger respondents are characterized by the manifestation of the "Hedonistic Present" factor, and at an older age - the important factor that is taken into consideration represent the Future factor.

Excessive concentration at one form of time is determined by such factors as culture, education, religion, membership in a social class. The preference for a specific time orientation is largely determined by the country of residence (national identification). In some societies (western), the value of autonomy and the future is encouraged, while in other cultures, on the contrary, orientation toward the past is supported [16, SYRCOVA, A., MITINA, O.V. i dr., 2007].

\section{SOURCES OF DATA AND USED METHODS}

The goal of our research is the investigation of the perception of time, values system by different age and ethnic groups in a transitional society.

One of the hypotheses of our research was the supposition that socio-economic changes occurring in the society will influence the values system, time perspective and the perception of present time by large social groups - age and ethnic groups.

In our research we made as well the hypothesis according to which the perception of time, values system by different social groups (age, ethnic) gives the possibility to understand from different perspectives the groups' state in a transitional society.

One can orient himself/herself in the new complex world, or understand it, only if he/she can in an appropriate way to interpret the ongoing processes, facts, otherwise he/she can "easily lose the meaning of both what is happening and his/her place in it".

Today, we consider an important task to understand and reveal the mechanisms "through which human being sees himself/herself as part of that reality in which he/she lives and acts, as well as all the factors that determine these processes" [2, ANDREEVA, G.M, 2009.].

THE METHODOLOGICAL BASIS of our investigation represents the systemic approach and social 
constructivism. Our basic hypotheses in the give research are the following:

1) The awareness of the world represents the result of mutual activity of people; "their relations, words used to define / describe social processes are meaningful and significant only in the context of these relations";

2) The widespread presence of certain form of understanding depends on the character of social processes, and the rule "how to define or name things", is determined by the character of social changes [17, ANDREEVA, G.M., 2009].

In the given article we are going to present a part of our empirical research - the perception of time by youngers; by ethnic groups (Kaunenco I.); and peculiarities of values system in groups of early aged adolescents (Gasper L.).

The scientific novelty of our research represents the determination of peculiarities of values system, the perception of present time by large social groups (age and ethnic) in transitional society, namely: planning time perspective, variability in the attitude to present time, hierarchy of values system as bases for the formation of collective subjectivity.

THE CHARACTERISTICS OF SAMPLE AND METHODOLOGY OF THE EMPIRICAL STUDY

Regions of research - Chisinău municipality, ATU Gagauzia (Autonomous Territorial Unit of Gagauzia) - Comrat, Chirsova village; Tvardita city; Rișcani district, Malinovscoe village; Cahul district, Lucești village; Singerei city. (Period of research - May-September 2016). Leova district, Cazangic village; Telenesti district, Negureni village. (Period of research - April 2019) (57 respondents aged 15-17); focus-groups organized in: Bălți municipality (14 respondents) and Comrat city (17 respondents).

Table 1

Sample structure

\begin{tabular}{|l|c|c|}
\hline Ethnic group & Nr. of respondents & Age (average) \\
\hline Russians & 40 & $\mathrm{~A}=39$ \\
\hline Bulgarians & 36 & $\mathrm{~A}=39$ \\
\hline Gagauz people & 40 & $\mathrm{~A}=41$ \\
\hline Ukrainians & 36 & $\mathrm{~A}=41$ \\
\hline Total & 152 & \\
\hline
\end{tabular}

Source: Elaborated by the author.

\section{Characteristics of sample in focus groups (2018)}

The sample in Bălți city was composed by young people aged 20-40 (14 respondents), from this reason the questions regarding the time perspective, the experience of present time in the period of society transformation had a vivid and consistent character. The educational statute: young people had completed higher education, or were studying at university (Cycle 1), or master cycle (Cycle 2). The focus group of Comrat city (17 respondents), from the age point of view was mixed, that is why in the given article we analyze the results of researching young people only.

Methodology: 1) Method "Scale of time attitudes" [10, NÛTTEN, Ž., 2004]. 2) In order to research the time perspectives we used the question: "For what period you can plan your life?" and there were some options of answer that characterize different length of the planning period. The given question was borrowed from the research of N. M. Lebedeva and A. N. Tatarco [8, LEBEDEVA, N.M., TATARKO, A.N., 2007] related to the time perspective. 3) Semi-structured interview regarding the perception of time (focus groups). 4) In order to study the values system of respondents represented by adolescents of early age we used the method of E. B. Fantalova (1992) [7, KRIVCOVA, S.V., 1997].

THE RESULTS OF THE EMPIRICAL RESEARCH AND THEIR ANALYSIS. The empirical research of time perspective of the groups of - Russians, Bulgarians, Gagauz people, Ukrainians reveals that the respondents of the given groups actually use to plan their future for a very short period of time from 1 to 5 years. Thus a significant number of respondents can plan their future for 1-5 years: $50 \%$ of Russians, $40 \%$ of Gagauz people, 38,9\% of Bulgarians, $44,4 \%$ of Ukrainians. But there is a big part of people that cannot plan at all $-37,5 \%$ of Russians, $41,7 \%$ of Ukrainians, $41,7 \%$ of Bulgarians, $40 \%$ of 
Gagauz people. The rest of answers were chosen by insignificant number of respondents. Thus, in present time, the representatives of researched ethnic groups don't develop a long time perspective. In every ethnic group half of respondents or a little less of half (Gagauz people, Bulgarians, Ukrainians) can plan their life from 1 to 5 years.

In our research we studied as well the perception of present time by the respondents of ethnic groups.

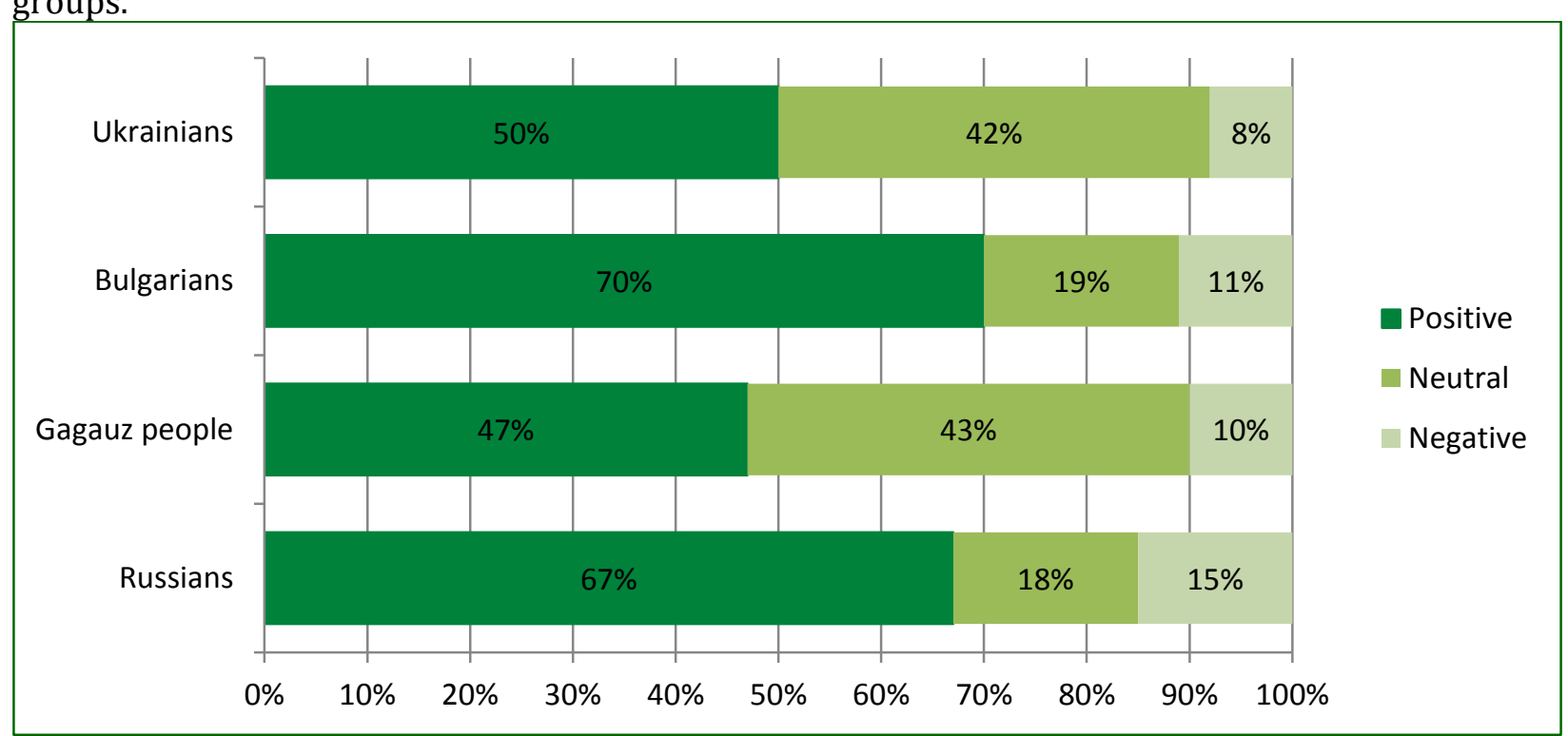

Figure 1. The perception of present time by respondents

Source: Author's calculations.

According to the results presented in diagram, regarding the perception of present time in Gagauz people (fig. 1), the positive attitudes are lesser emphasized (47\%). Gagauz people (43\%) and Ukrainians (42\%) are characterized by neutral attitude towards time.

As well, we can see that in the groups of Russians (67\%) and Bulgarians (70\%) positive perception of present time dominates, and the results regarding the neutral perception of time is lower (Russians 18\%; Bulgarians 19\%).

Thus, we can conclude that the present time is perceived more positively by the groups of Russians and Bulgarians, less positive perception is dominating in the group of Gagauz people. The groups of Ukrainians and Gagauz people are more characterized by neutral attitudes regarding the perception of present time.

THE RESULTS OF ANALYSIS OF THE PROFILES OF ATTITUDES TO PRESENT TIME IN RESEARCHED ETHNIC GROUPS, QUALITATIVE ANALYSIS

The group of Gagauz people perceives the present time as important, swift, full of hope, wonderful, familiar. Among negative features of the present time perception, the respondents from this group mentioned often - difficult, threatening. Such characteristics of present time in Gagauz people as short, externally determined, passive waiting, closed, enjoyable are more "dispersed". Concerning these characteristics of present time perception, the respondents are more uncertain. Thus, the perception of present time by the group of Gagauz people is characterized as swift, full of hope, wonderful, at the same time threatening and difficult.

The group of Russians perceives the present time as full, interesting, swift, open, familiar, everchanging, important, successful (completed). Among negative characteristics there are - difficult, short. Russians are uncertain regarding the following features: attractive - threatening, my personal - determined externally, warm - cold, distant - close, pleasant - unpleasant. Thus, the group of Russians perceives the time as full, interesting, swift, open, familiar, ever-changing, important, successful (completed), and at the same the time is - difficult and short.

The group of Bulgarians perceives the present time as ever-changing, pleasant, full, important, 
my personal, wonderful, swift, full of hope, interesting. Concerning the negative characteristics of present time, they mentioned - difficult. The group of Bulgarians is uncertain regarding the following features of present time: easy - difficult, warm - cold, completed - disappointing, long -short, attractive - threatening.

The group of Ukrainians perceives the present time as open, important, full, swift, wonderful, ever-changing, full of hope. Negative characteristics - difficult, cold. Regarding the following features there is no consensus: warm - cold, full - empty, attractive - threatening, long -short, completed disappointing, i.e. successful - unsuccessful, personal - determined externally. As we can see, the group of Ukrainians, generally, perceives time positively, but it is also dividing concerning success and failure in time, personal - determined externally, i.e. depending on locus of control. Thus, all these ethnic groups perceive time as ever-changing, open, swift, important, at the same time difficult and threatening. For a better understanding of time perception at the group level by different social groups, not only the quantitative tools are important but also the qualitative methods, such as working in focus groups.

THE RESULTS OF RESEARCHING THE PERCEPTION OF TIME BY YOUNG PEOPLE IN FOCUS GROUPS. In the given article we combined the empirical material gathered from focus-groups realized in Bălți municipality and Comrat city (ATU Gagauzia). We divided conditionally the following groups of youngers according the perception of present time.

1. "Optimists"

The main message of this group is the following: "The time is 'mine', and it is interesting to live in it". They are confident in their good future, they can keep up with times, they can develop themselves both professionally and personally ("I feel comfortable"). They have professional accomplishments (they are successful regarding the professional accomplishments), often due to the involvement in international cooperation. Although with reservations, they characterize time as difficult and complicated for people around them, especially for the older generation. They disagree with the assessment of the parents regarding the definition of the present: "Parents always share with us, then it was like that, maybe..., they think that it was better then. We don't think so. I feel comfortable, maybe not $100 \%$. I would not say that all areas are ideal as I would like", "I believe that my time, despite the decline in the country, can still grow." Time is perceived by respondents of this group as dynamic, technological, motivates them for the future: "...I feel the changes, everything is moving so fast, it is developing so fast, I like it. I can also change in parallel with time. Society is developing dynamically, such information leaps happen, which is difficult follow. But I like it, I feel that this era is mine, and I have a good future." A quick change of events does not scare them, does not give rise to a sense of anxiety, but rather, creates a comfortable state.

Our respondents, according to their age, in their majority, refer to the generation "millennium", and it is characterized by such values as - "freedom", "creation", "entertainment"; every "millennium" begins feel unique and unrepeatable. Max Prenski defines the "millennium" generation through its interaction with informational technologies - "digital aboriginals" [4]. "News", "lot of events" motivate such generation, "lure" them and create the "comfort zone" as in the perception of present time, as well as of the future.

2. «Positive fatalists»

The positive-fatalistic attitude to the present is "as it will be, it will be so". The respondents of this group worry that they don't have time to realize everything, and someone "as far as possible": "the time is mine, when I have time, when I don't have time. As far as possible. They are anxious in terms of money, finances, when they are enough / not enough. Normal time, I don't know another." For the respondents of this group, professional realization plays a big role, and the marker of the present is the opportunity to get an education abroad, to participate in international projects.

3. «Socially-anxious»

These respondents perceive present time as "fragile", "unstable", "volatile", there is no certainty about "anything". An important factor in the perception of the present time by respondents represents the socio-economic situation in the country: "As for planning, I can say that it all depends on our stability in this country. How can one plan something for the future without knowing what will happen to this country. For a long period you cannot plan, because there is no certainty about 
anything. Even with regard to the financial side, you cannot take out a loan, because there is no stability in work, and there are no other sources of subsistence. ... I can plan for several days in advance, I can also plan the implementation of family issues. You cannot even plan a trip because you do not know whether you will have time for this or not ... We are at an age when everything changes. We want more. Many want to live today, the present, for the future you need to be optimistic". The respondents in this group revealed difficulties in controlling time, its successful management, and the inability to organize a sequence of events. The prospect of the future is difficult, and it is possible to predict difficulties with time integration, at least at this time stage.

It seems that this type of perception of time today will be characteristic of a significant part of youth. And we can speculate that this inability to manage time due to institutional instability will be one of the "pushing" factors for inclusion in labor migration or emigration. The participants of the focus-groups mentioned these options as possible.

In the process of researching the perception of time by different ethnic and age groups, an idea was born - to carry out a pilot comparative study on labor migrants that are working in Italy [18, $\mathrm{p}$. 53-56].

We wanted to get answers for the following question: How the labor migrants perceive the socio-cultural changes in our country? We conducted a survey of 17 respondents - Moldovans that are working in Piacenza city, in the southeast of Italy. The survey, on our request, was conducted by Tat'yana Roshka, a PhD student at ULIM, in august 2018. The age of the selected sample was between 40-60 years. The given research has a pilot character. The survey had three questions: "When you are back in Moldova, what changes are mostly obvious, from your point of view?", "Do you want your children to remember the Republic of Moldova?", "What they should remember?".

We will describe shortly the results of this empirical study.

1. According to the perception of labor migrants, the socio-cultural changes in the country are noticed in material sphere and in the interpersonal relationships. The dispersion of perceptions is characterized by polarization, from extremely positive to negative, with the dominance of the positive.

2. In the content of ethno-cultural transmission by parents to their children, a positive attitude to homeland, country dominates. The majority of parents want children to remember and to preserve national traditions which will be, as we suppose, an important marker in preserving the ethnic identity in young "Italian Moldovans". Along with this, the labor migrants have also negative experiences of the country (embarrassment regarding the material/financial difficulties both in homeland and Italy, in the beginning of their emigrant history).

For psychologists, the value sphere presents a specific interest being an extremely generalized social experience obtained by a person in ontogenesis, as elements of a single semantic field [11, POČEBUT, L.G., 2003]. Values are a powerful sense-forming, motivating construct forming the "picture of the world" in adolescence and youth. Further, as researches show, the value system remains fairly stable, despite even the socio-economic systemic changes in young, mature ages [19, GAVRELIUC, D., GAVRELIUC, A., 2018].

To understand the genesis of personal development in adolescence, during the period of transitivity, we conducted a study of their value system. We briefly dwell on the results of the empirical study. We insist to mention an interesting fact got in the research - the difference between the 'Value' and 'Accessibility' indicators, which reflects the level of mismatch, disintegration in the value-motivational sphere of the individual. It characterizes its internal conflict as a "blockade" of leading needs on the one hand, and self-realization, personal identity on the other. We have identified a conflict in the values of 'Health' and 'Happy family life', as very significant, but difficult to access. We suppose that many of our respondents, residents of rural areas, have parents included in labor migration. And perhaps the family, its social practices represent an unsatisfied need - in emotionally close relationships with relatives, which are often episodic, "virtual" in nature (during the period when the parents come from abroad or communicate on the Internet). The value of 'Health', this is perhaps a reflection of communication with loved ones, regarding the labor market - where health and physical endurance are important. Based on the average indicators (attractiveness, value) of various life spheres, we compiled a rating of adolescents' values. 


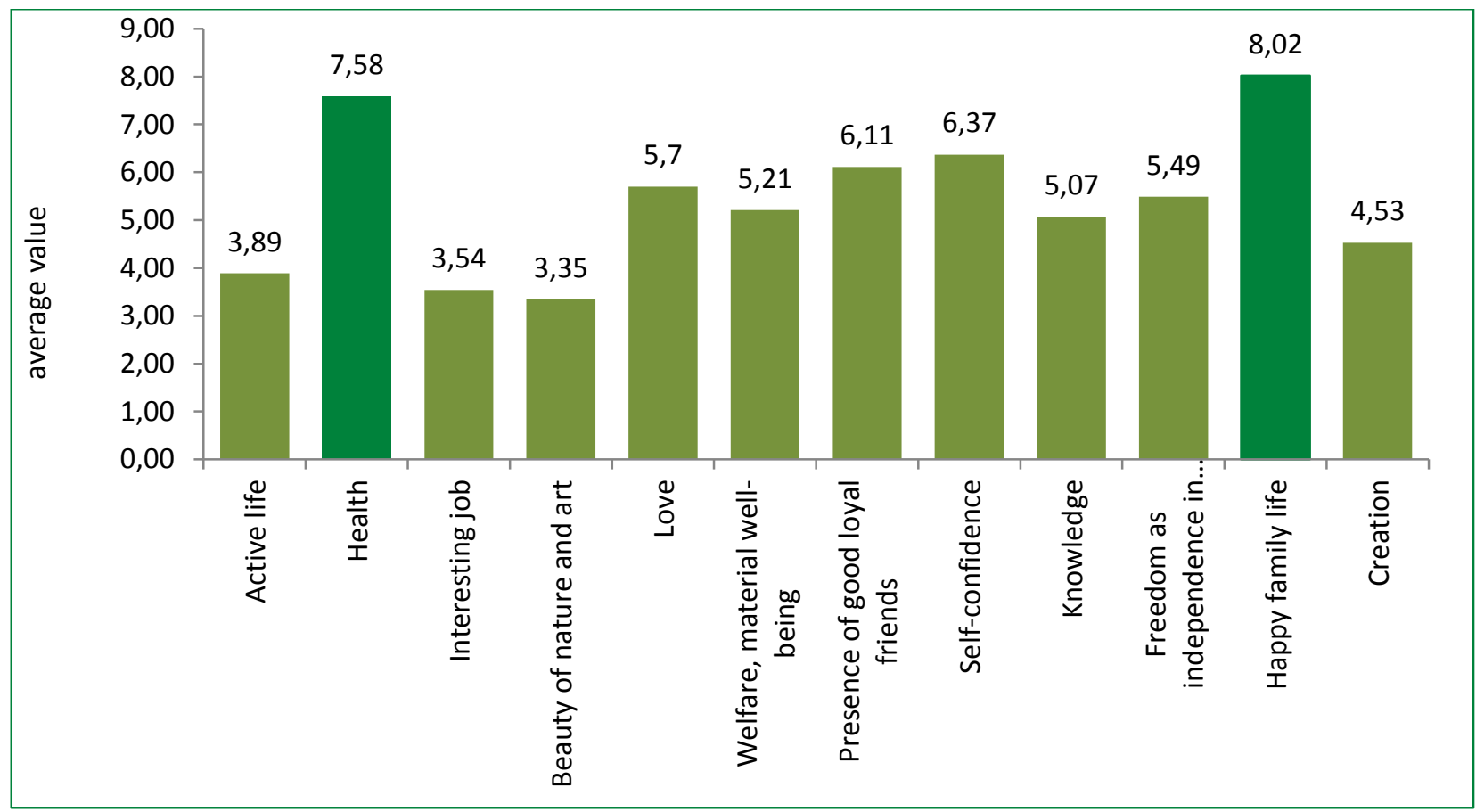

Source: Author`s calculations.

Figure 2. Values rating

As we can see, from the presented results of the given empirical study, the spheres "Happy family life" and "Health" have the highest values. The respondents value the least such spheres as "Beauty of nature and art", "Interesting job". Apparently, this is determined by the pragmatism of modern public life, in which first of all things that are worthwhile and worthy are valued, and "interesting work", which would be well paid, is a rare guest in our regional space in the views of our young respondents.

It's interesting the fact, that researcher Kaunenco I. I. in her study on values system of Moldavian young students in 2019, by means of S. Schwartz method, has determined that such values as "family protection", "health" were the most preferred, significant values, having the smallest spread of data. The least preferred values were "creativity", "the world of beauty", "spiritual life", presenting a big discrepancy of attitudes among the respondents' hierarchization. Such a hierarchy of values is characteristic for countries in a situation of survival, rather than self-realization (such as countries of the European space). The conducted factor analysis of the value sphere of student youth has revealed both an orientation towards both traditional and innovative values, and one of the factors was called "Cultural Crossroads". Where does the value-time pendulum swing in different social groups, this is a study field for further research.

It seems to us that at present, studying the perception of time and the value system of different social groups will help to understand and predict the vector of the future socio-cultural development of our region.

\section{CONCLUSIONS}

1. The research of the time perspective of the representatives of ethnic groups revealed that they actually plan their future for a very short period of time from 1 to 5 years. Concerning the perception of present time, in the groups of Russians, Bulgarians a positive perception dominates, in the group of Ukrainians - the group perception is divided in two, and the less positive perception is peculiar for the group of Gagauz people. In the groups of Gagauz people and Ukrainians neutral attitudes are more emphasized regarding the perception of present time. In all ethnical groups the present time is perceived as ever-changing, open, swift, important, and at the same time, difficult and threatening.

2. The groups of youngers that we divided conditionally according to the time perception, from 


\begin{abstract}
"optimists" to "socially-anxious", indicate the patchiness of our society, that include resourceful generational and reform potential (youngers - "optimists") as well as the group, that in the conditions of continuous decline of the social-economic development of the region, has the tendency to migrate, because "nothing can be planned in the future".

3. The research of values system of the respondents adolescents, revealed the unsatisfied need in the emotional-personal familial relations, in positive family practices, and anxiety regarding the value "Health" as resource of the potential of labor migration.

The research of time perception and values system in different social groups is promising taking into consideration the society need for normal functioning of social institutions. The success of their functioning depends on the values system of citizens and strong belief in the prospect of common positive future.

It seems promising to research the options for responding groups - age, ethnic to systemic socio-economic changes in society. It is also necessary to study the national mentality of our region, since social institutions can function successfully only with the "support" of the mentality.
\end{abstract}

\title{
REFERENCES
}

1. ANDERSON, Benedikt. Voobražaemye soobŝestva. Razmyšlenia ob istokah i rasprostranenii nacionalizma. Moskva: Kučkovo pole, 2016. 416 s. ISBN 5-93354-017-3.

2. ANDREEVA, G.M. K voprosu o progresse v social'noj psihologii. V: G.M. ANDREEVA. Social'naâ psihologiâ segodnâ: poiski i razmyšleniâ. Otv.red. O.V.KRASNOVA.Moskva: NOU VPO MPSI, 2009, ss. 7-36. ISBN 978-5-9770-0446-6.

3. Social'noe vospriâtie - ishodnyi punkt. V: G.M. ANDREEVA. Psihologiâ social'nogo poznaniâ. Moskva: Aspekt Press, 2000, ss. 43-51. ISBN 5-7567-0248-2.

4. BEZBOGOVA, M.S., IONCEVA, M.V. Social'no-psihologičeskij portret sovremennoj molodeži. V: Mir nauki. 2016, tom 4, nomer 6. ISSN 2309-4265. [Accesat 23.09.2019]. Disponibil: https://mirnauki.com/PDF/35PSMN616.pdf

5. BOGOMOLOVA, N.N., DONCOV, A.I., FOLOMEEVA, T.V. Psihologiâ bol'ših social'nyh grupp: novye sud'by, novye podhody. V: T.L. ALAVIDZE, G.M. ANDREEVA i dr. Sovremennaâ psihologiâ v sovremennom. Moskva: Aspekt Press, 2002, ss. 132-148.

6. DILEGENSKIJ, G.G. Social'no-političeskaâ psihologiâ. Moskva, 1994. 304 s. ISBN 5-02-013558.

7. KRIVCOVA, S.V. Podrostok na perekrestke èpoh. Moskva: Genezis, 1997. 280 s. ISBN 5-85297004-2.

8. LEBEDEVA, N.M., TATARKO, A.N. Cennosti kul'tury i razvitie obŝestva. Moskva, 2007. 499 s. ISBN 978-5-7598-0498-7.

9. NESTIK, T.A. Social'naâ psihologiâ vremeni. Moskva: Iz-vo Institut Psihologii RAN, 2014. 496 s. ISBN 978-5-9270-0282-5.

10. NÛTTEN, Ž. Motivaciâ, dejstvie i perspektiva budushŝego. Pod red. D.A. LEONT'EVA. Moskva: Smysl, 2004. 608 s. ISBN 5-89357-151-7.

11. POČEBUT, L.G. Psihologiâ social'nyh obŝnostej (tolpa, socium, ètnos): avtoreferat dissertacii na soiscanie učenoj stepeni doktora psihologičeskih nauk. SPb, 2003. $46 \mathrm{~s}$.

12. KAUNENKO, I.I. Vospriâtie vremeni ètničeskim gruppami Respubliki Moldova: social'nopsihologičeskij aspekt. In: Ştiinţă, educaţie, cultură: conferinţă ştiinţifico-practică internaţională. Komrat: Tipografia "A\&V Poligraf, 2019, vol. 1, pp. 487-491. ISBN 978-9975-3246-4-9.

13. MARCINKOVSKAÂ, T.D. Istoriâ, kul'tura, razvitie kak obrazuûŝie istoriko-genetičeskoj paradigmy. V: Kul'turno istoričeskaâ psihologiâ. 2015, tom 11. № 4, ss. 69-78. ISSN 1816-5435.

14. EMEL'ÂNOVA, T.P. Konstruirovanie social'nyh predstavlenij v usloviâh transformacii rossijskogo obŝestva. Moskva: Izd-vo «Institut psihologii RAN», 2006. $400 \mathrm{~s}$.

15. KUZNECOVA, A.V. Kollektivnaâ pamât' o značimyh sobytiâh i figurah rossijskoj istorii v različnyh social'nyh gruppah: dissertaciâ na soiskanie naučnoj stepeni kandidata psihologičeskih nauk. Moskva, 2013. $166 \mathrm{~s}$.

16. SYRCOVA, A., MITINA, O.V. i dr. Fenomen vremennoj perspektivy v raznyh kul'turah (po materialam issledovanij s pomoŝ'û metodiki ZTPI). V: Kul'turno-istoričeskaâ psihologiâ. 2007, tom 3, № 4, ss. 19-31. ISSN 1816-5435. 
17. ANDREEVA, G.M. Social'naâ psihologiâ: vektory novoj paradigmy. V: Psihologičeskie issledovaniâ. 2009, № 1 (3). ISSN 2075-7999. [Accesat 15.10.2019]. Disponibil: http://psystudy.ru/index.php/num/2009n1-3/55-andreeva3.html

18. KAUNENKO, I.I. Vospriâtie sociokul'turnyh izmenenij v Respublike Moldova trudovymi migrantami moldavanami. V: Moldova i Gagauziâ v kontekste razvitiâ moldavskoj gosudarstvennosti: Naučnopraktičeskaâ konferenciâ s učastiem učonyh Respubliki Moldova posvâŝennaâ 660-letiû moldavskoj gosudarstvennosti, 17 sentâbrâ 2019. Komrat, 2019, ss. 53-56.

19. GAVRELIUC, D., GAVRELIUC, A. Generational Belonging and Historical Ruptures: Continuity or Discontinuity of Values and Attitudes in Post-Communist Romania. In: N. LEBEDEVA, R. DIMITROVA, J. BERRY (eds.). Changing values and identities in the post-communist world. Societies and political orders in transition. Springer, 2018. pp. 207-222. [Accesat 23.09.2019]. Disponibil: https://www.springer.com/gp/book/9783319726151

\section{ARTICLE HISTORY}

Received 01 October 2019

Accepted 15 November 2019 